\title{
KAJIAN KEBERLANJUTAN AGRIBISNIS HORTIKULTURA DI KABUPATEN SUMBA BARAT
}

\author{
Oleh \\ Dr. Ernesta Leha, S.E., M.Agb \\ Dosen Program Studi Ekonomi Pembangunan \\ e-mail: ernestaleha@gmail.com
}

\begin{abstract}
ABSTRAK
Sumba Barat adalah salah satu kabupaten di Pulau Sumba Provinsi Nusa Tenggara Timur. Hortikultura merupakan produk pertanian yang cukup diminati di Sumba Barat. Potensi pasar untuk komoditas hortikultura di Sumba Barat cukup besar namun produksinya masih rendah. Untuk itu dilakukan penelitian dengan tujuan untuk (1) mengetahui status keberlanjutan pengembangan agribisnis hortikultura di Sumba Barat dan (2) mengetahui atribut yang dominan mempengaruhi status keberlanjutan pengembangan agribisnis hortikultura di wilayah tersebut. Hal ini penting karena keberlanjutan berkaitan dengan kemampuan suatu wilayah meningkatkan produksi di sektor pertanian termasuk sub sektor hortikultura. Studi ini menggunakan metode analisis Multi Dimentional Scaling (MDS), yang merupakan modifikasi dari Metode Rapid Appraisal of the Status of Farming (RAP-farm). Hasil analisis MDS menunjukkan bahwa (1) Kabupaten Sumba Barat berada pada status cukup berkelanjutan untuk dimensi sosial dan kelembagaan sedangkan untuk dimensi ekologi, ekonomi dan teknlogi berada pada status kurang berkelanjutan dan (2) atribut yang dominan berpengaruh pada masing-masing dimensi adalah (a) dimensi ekologi dipengaruhi oleh tingkat kemiringan lahan dan tingkat erosi yang terjadi; (b) dimensi ekonomi dipegaruhi oleh pengelolaan hasil hortikultura, kontribusi terhadap pendapatan per kapita; (c) dimensi sosial dipengaruhi oleh eksistensi rumah tangga hortikultura dan eksistensi layanan pemerintah; (d) dimensi teknologi oleh teknologi konservasi tanah dan air serta penerapan teknologi; (e) dimensi kelembagaan dipengaruhi oleh konflik antar kelompok tani, ketersediaan lembaga pemasaran dan jumlah penyuluh pertanian
\end{abstract}

\section{Kata kunci : produksi, hortikultura, agribisnis, atribut, dominan, keberlanjutan}

\begin{abstract}
West Sumba is one of the regencies in Sumba island province of East Nusa Tenggara. Horticulture is a popular agricultural product there. The market potential for horticultural commodities in West Sumba is quite large but its production is still low. For this reason, the research was conducted with the aim of (1) knowing the sustainability status of horticultural agribusiness in West Sumba and (2) knowing the dominant attributes affecting the sustainability status of horticultural agribusiness development in the region. This is interesting to be examined since the sustainability is related to the ability of an area to increase production in the agricultural sector including the horticulture sub-sector. This study used the Multi-Dimensional Scaling (MDS) analysis method, which is modification of the Rapid Appraisal of the Status of Farming (RAPfarm) method. MDS analysis results show that (1) West Sumba Regency is in a fairly sustainable status for social and institutional dimensions while for the dimensions of ecology, economics and technology are in a less sustainable status and (2) the dominant attributes affecting each
\end{abstract}


dimension are (a) the ecological dimension is affected by the level of land slope and the level of erosion that occurs; (b) the economic dimension is affected by the management of horticultural products, the contribution to income per capita; (c) the social dimension is influenced by the existence of horticultural households and of government services; $(d)$ technological dimensions by soil and water conservation technology and the application of technology; (e) the institutional dimension is influenced by conflicts between farmer groups, the availability of marketing institutions and the number of agricultural extension instructor.

\section{Keywords: production, horticulture, agribusiness, attributes, dominant, sustainability}

\section{PENDAHULUAN}

Salah satu sub sektor pertanian yang berpotensi untuk dikembangkan dalam kerangka agribinis adalah hortikultura. Berdasarkan makna harafiahnya, hortikultura merupakan gabungan bahasa latin hortus yang berarti kebun dan colere yang berarti membudidayakan. (Roedhy et al 2014). Hortikultura dapat didefenisikan sebagai cara budidaya tanaman yang dapat dilakukan di kebun atau pekarangan. Hortikultura dikelompokkan atas 4 jenis komoditas yakni sayuran, buahbuahan, tanaman hias dan tanaman biofarma. Komoditas hortikultura terutama sayuran dan buahbuahan merupakan komoditas unggulan saat ini namun harus ditunjang oleh kondisi lahan dan iklim yang cocok serta didukung oleh potensi sumberdaya dan adanya peluang pasar domestik maupun internasional. Selain sebagai komoditas unggulan, hortikultura juga berperan sebagai sumber gizi masyarakat, penyedia lapangan kerja dan penunjang kegiatan agrowisata dan agroindustri (Ashari, 2006).

Pertumbuhan sub sektor hortikultura disebabkan oleh beberapa faktor pendukung yakni meningkatnya kebutuhan konsumsi masyarakat akibat peningkatan pendapatan per kapita, jumlah konsumen dan perubahan preferensi konsumen. Kebutuhan konsumsi tidak hanya untuk pasar di dalam negeri tetapi juga untuk pasar dunia karena perdagangan bebas sangat berpengaruh terhadap dinamika agribisnis hortikultura di setiap negara. Berbagai penelitian tentang pangan mengungkapkan bahwa konsumsi sayuran dan buah per kapita memiliki elastisitas pendapatan lebih besar dibandingkan konsumsi bahan pangan karbohidrat lainnya. Artinya, pembangunan ekonomi yang berdampak kepada peningkatan pendapatan rumah tangga akan menyebabkan peningkatan konsumsi per kapita yang lebih tinggi pada komoditas sayuran dan buah-buahan.

Sumba Barat merupakan salah satu kabupaten di Pulau Sumba dengan potensi hortikultura yang cukup tinggi. Dengan diberlakukannya UU No. 22 Tahun 1999 tentang Pemerintah Daerah, terjadi berbagai perubahan kewenangan pemerintahan di tingkat kabupaten dalam mengelola sumber daya yang ada di wilayahnya. Pasal 10 ayat 1 menyatakan bahwa daerah berwenang mengelola sumberdaya nasional di wilayahnya dan bertanggung jawab memelihara kelestarian 
lingkungan sesuai dengan peraturan perundang-undangan. Kebijakan desentralisasi tersebut diperkirakan akan mendorong setiap daerah, baik provinsi maupun kabupaten, untuk memproduksi berbagai komoditas pertanian dalam kerangka swasembada di tingkat daerah, atau paling tidak mengurangi ketergantungan terhadap daerah lain. Kebijakan semacam ini bisa sangat menguntungkan baik ditinjau dari penggunaan sumberdaya domestik maupun perdagangan antar wilayah (Rosidin, 2015).

Komoditas buah-buahan yang dikembangkan di Sumba Barat adalah alpukat, mangga, rambutan, jeruk, jambu biji, sirsak, papaya, nenas, salak dan nangka. Sedangkan komoditas sayuran terdiri atas wortel, kacang merah, kacang panjang, cabai, tomat, terung, buncis, bawang merah, bawang putih, bawang daun, kentang, kubis, petsay, ketimun, labu siam, kangkung dan bayam. Persoalan utama yang berkaitan dengan budidaya hortikultura di Sumba Barat adalah nilai produksinya yang masih rendah, dan presentasenya yang sangat kecil baik dalam skala provinsi maupun nasional. Jumlah produksi hortikultura yang rendah di Sumba Barat selama 5 tahun terakhir menunjukan bahwa kondisi pengembangannya kurang berkelanjutan. Komoditas buahbuahan mengalami peningkatan tetapi dalam jumlah yang kecil yakni 4,5\% dari tahun $2014-2016$ dan 0,21\% dari tahun 2016 - 2018. Sedangkan komoditas sayuran justru mengalami penurunan dari tahun 2014 - 2016 sebesar (14,36)\% dan meningkat dari tahun 2016 - 2019 sebesar 1,72. Penurunan nilai produksi ini menyebabkan terjadinya ketergantungan yang tinggi akan produk hortikultura dari daerah lain yang berdampak pada tingginya harga sayuran dan buah buahan di Kabupaten Sumba Barat.

Tabel 1. Pertumbuhan Produksi Hortikultura di Kabupaten Sumba Barat (2014 - 2018)

\begin{tabular}{llclcc}
\hline \multirow{2}{*}{ Komoditas } & \multicolumn{3}{c}{ Produksi (Ton) } & \multicolumn{2}{c}{ Pertumbuhan (\%) } \\
\cline { 2 - 6 } & 2014 & 2016 & 2018 & $2014-2016$ & $2016-2018$ \\
\hline Buah-buahan & 8135 & 8503 & 8521 & $4.5 \%$ & $0.21 \%$ \\
Sayuran & 9827 & 8416 & 8561 & $-14.36 \%$ & $1.72 \%$ \\
\hline \multicolumn{3}{c}{ Sumber $:$ Sumba Barat Dalam Angka, 2015 dan 2019 }
\end{tabular}

Luas lahan hortikultura di Kabupaten Sumba Barat masih terbatas tetapi potensi sumberdaya lahan kering untuk pengembangan hortikultura masih tersedia. Luas lahan kebun/tegalan sebesar 14.373 ha, ladang/huma seluas 8.099 ha dan lahan sementara yang tidak diusahakan adalah 5.627 ha. Semua lahan kering tersebut sangat potensial untuk dikembangkan sebagai lahan hortikultura dengan tujuan pasar domestik yakni Pulau Sumba dan pulau-pulau lain di Provinsi NTT, NTB dan Provinsi Bali. 
Selain luas lahan, Sumba Barat juga memiliki potensi lain yang menjadi faktor pendukung pengembangan agribisnis hortikultura yakni (1) kaya akan plasma nutfah hortikultura sebagai sumber keanekaragaman genetik; (2) potensi sumberdaya manusia atau tenagakerja yang berlimpah; (3) modal sosial (social capital) yang tinggi; (4) memiliki empat kelebihan alam yang tidak dimiliki oleh sebagian besar wilayah lain yakni panjang dan intensitas penyinaran, suhu, bebas angin topan, dan curah hujan yang jauh lebih tinggi daripada kabupaten lain di Pulau Sumba sehingga memungkinkan untuk dilakukan rotasi tanam tiga sampai empat kali dalam setahun.

Pengembangan Kawasan Agribisnis Hortikultura (PKAH) merupakan salah satu implementasi kebijakan Kementerian Pertanian, dimana pembangunan komoditas unggulan diarahkan pada pengembangan kawasan yang terpadu secara vertikal dan/atau horizontal dengan konsolidasi usaha produktif berbasis lembaga ekonomi masyarakat yang berdaya saing tinggi di pasar lokal maupun internasional. (Dirjen Hortikultura 2017). Implementasi program ini harus berdasarkan asas keberlanjutan, yang mencakup aspek ekologis, sosial dan ekonomi (Sadjat, 2002). Untuk itu dalam penelitian ini akan dikaji tentang (1) status keberlanjutan agribinis hortikultura di Kabupaten Sumba Barat dan (2) atribut yang dominan mempengaruhi keberlanjutan agribisnis hortikultura di Sumba Barat ditinjau dari lima dimensi yakni dimensi ekologi, ekonomi, sosial, teknologi dan kelembagaan. Tujuannya adalah untuk mengetahui status dan atribut yang dominan mempengaruhi keberlanjutan sistem agribisnis hortikultura di wilayah tersebut.

\section{METODE PENELITIAN}

\subsection{Lokasi Penelitian}

Penelitian dilakukan di Kabupaten Sumba Barat, Pulau Sumba, Provinsi Nusa Tenggara Timur sejak bulan Juni sampai Desember 2019.

Gambar 1. Peta Pulau Sumba dan Kabupaten Sumba Barat

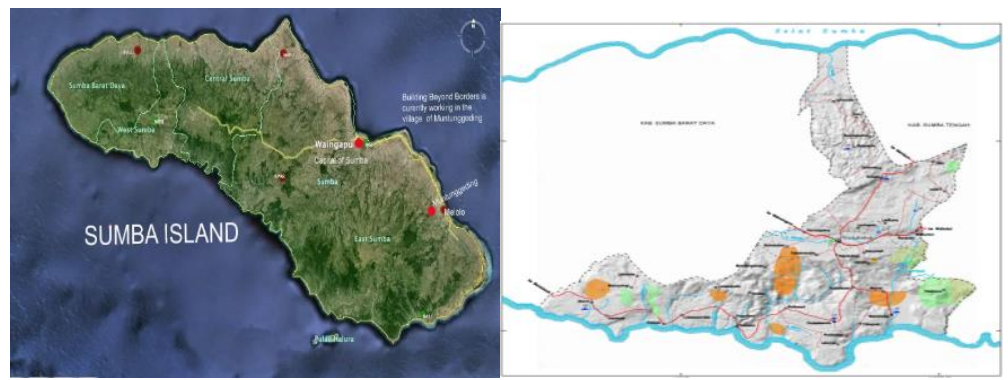


Kabupaten Sumba Barat terletak antara 90 22' - 90 47' Lintang Selatan (LS) dan 1190 08'1190 32’ Bujur Timur (BT). Berdasarkan posisi geografisnya, Kabupaten Sumba Barat memiliki batas di sebelah Utara berbatasan dengan Selat Sumba, sebelah Selatan berbatasan dengan Samudera Indonesia, sebelah Barat berbatasan dengan Kabupaten Sumba Barat Daya dan sebelah Timur berbatasan dengan Kabupaten Sumba Tengah.

Kabupaten Sumba Barat terdiri atas 6 kecamatan, yaitu Lamboya, Wanokaka, Laboya Barat, Loli, Kota Waikabubak, dan Tana Righu. Kecamatan yang paling luas adalah Lamboya Barat dengan luas $161,23 \mathrm{~km}^{2}$ atau $21,86 \%$. Kecamatan yang paling kecil adalah Kota Waikabubak dengan luas $44,71 \mathrm{~km}^{2}$ atau $6,06 \%$. Luas wilayah pada setiap kecamatan selengkapnya tersaji pada Tabel 2.

Tabel 2. Luas Wilayah Menurut Kecamatan di Sumba Barat

\begin{tabular}{clcc}
\hline No & \multicolumn{1}{c}{ Kecamatan } & Luas $\left(\mathrm{km}^{2}\right)$ & Persentase \\
\hline 1 & Lamboya & 125,65 & 17,04 \\
2 & Wanokaka & 133,68 & 18,13 \\
3 & Lamboya Barat & 161,23 & 21,86 \\
4 & Loli & 132,36 & 17,95 \\
5 & Kota Waikabubak & 44,71 & 6,06 \\
6 & Tanarighu & 139,79 & 18,98 \\
\hline$\quad$ Sumba Barat & 737,42 & 100,00 \\
\hline
\end{tabular}

Sumber : Sumba Barat Dalam Angka, 2019

Kabupaten Sumba Barat memiliki luas daratan mencapai 737,42 km2. Sebagian besar wilayahnya berbukit-bukit dimana hampir 50 persen luas wilayahnya memiliki kemiringan $140^{0}$ $400^{\circ}$. Seperti halnya di tempat lain di Indonesia, di Kabupaten Sumba Barat hanya dikenal 2 musim yaitu musim kemarau dan musim hujan. Pada bulan Juni sampai dengan September arus angin berasal dari Australia dan tidak banyak mengandung uap air, sehingga mengakibatkan musim kemarau. Sebaliknya, pada bulan Desember sampai dengan Maret arus angin banyak mengandung uap air yang berasal dari Asia dan Samudera Pasifik, sehingga terjadi musim hujan.

\subsection{Jenis dan Sumber Data}

Jenis data yang digunakan dalam penelitian ini adalah data primer berupa atribut atau parameter yang terkait dengan lima dimensi keberlanjutan agribisnis hortikultura yaitu dimensi ekologi, ekonomi, sosial, teknologi dan kelembagaan. Setiap dimensi terdiri dari beberapa parameter yang merupakan modifikasi dari Kepmen Lingkungan Hidup No.201 Tahun 2004, Barbour et al. (2004), Pitcher dan Preikshot (2001), Theresia et al (2015), Pattimahu (2010) dan 
hasil observasi serta wawancara (Tabel 4). Data primer bersumber dari hasil wawancara terhadap responden dan pakar yang dipilih, serta hasil pengamatan di lokasi penelitian. Sedangkan data sekunder adalah data-data statistik yang bersumber dari BPS dan dinas-dinas terkait.

\subsection{Metode Analisis}

Metode yang digunakan dalam penelitian ini adalah Rapid Appraisal for Fisheries (RAPFISH) berbasis multidimensional scaling (MDS) yang dimodifikasi untuk mengetahui keberlanjutan agribisnis hortikultura di wilayah penelitian (Pitcher and Preikshot 2001). Metode MDS adalah proses untuk memetakan obyek atau titik yang diamati dalam satu ruang, dimana obyek atau titik yang sama dipetakan saling berdekatan dan obyek atau titik yang berbeda dipetakan berjauhan (Fauzi dan Anna 2002). Hasil analisis MDS dinyatakan dalam nilai indeks (0-100) yang mencerminkan status keberlanjutan terhadap objek kajian berdasarkan kondisi aktual dan ordinasinya pada setiap dimensi (Tabel 3).

Tabel 3. Indeks dan Status Keberlanjutan

\begin{tabular}{cc}
\hline Nilai Indeks & Kategori \\
\hline $0.00-25.00$ & Buruk : Tidak berkelanjutan \\
$25.01-50.00$ & Kurang : Kurang berkelanjutan \\
$50.01-75.00$ & Cukup : Cukup berkelanjutan \\
$75.01-100.00$ & Baik : Sangat berkelanjutan \\
\hline
\end{tabular}

Sumber : Pitcher and Preikshot, 2001

Secara umum, ada tiga tahapan dalam analisis keberlanjutan, yaitu (1) penentuan atribut pada setiap dimensi keberlanjutan; (2) penilaian atribut pada setiap dimensi keberlanjutan menggunakan kuesioner penelitian; (3) penilaian indeks dan status keberlanjutan melalui analisis ordinasi, analisis sensitivitas (leverage analysis) dan analisis anomali (Monte Carlo analysis). Berdasarkan ketiga tahapan ini maka akan diketahui status keberlanjutan wilayah yang diteliti.

Atribut yang digunakan untuk mengetahui status keberlanjutan agribisnis hortikultura di Sumba Barat dipetakan dalam 5 yaitu dimensi keberlanjutan yakni dimensi ekologi (8 atribut), ekonomi (7 atribut), sosial (8 atribut), teknologi (7 atribut) dan kelembagaan (7 atribut), selengkapnya terangkum dalam Tabel 4. 
KAJIAN KEBERLANJUTAN AGRIBISNIS HORTIKULTURA DI KABUPATEN SUMBA BARATErnesta Leha

Tabel 4. Atribut Keberlanjutan Agribisnis Hortikultura di Sumba Barat

\begin{tabular}{|c|c|c|c|}
\hline No & $\begin{array}{c}\text { Dimensi } \\
\text { Keberlanjutan }\end{array}$ & No & Atribut Keberlanjutan \\
\hline \multirow[t]{8}{*}{1} & Ekologi & 1.1 & Pengelolaan lahan \\
\hline & & 1.2 & Tingkat kemiringan lahan \\
\hline & & 1.3 & Kondisi penutupan lahan \\
\hline & & 1.4 & Tingkat erosi yang terjadi \\
\hline & & 1.5 & Penggunaan pupuk dan pestisida \\
\hline & & 1.6 & Ketersediaan pupuk organik \\
\hline & & 1.7 & Kualitas hasil tanaman \\
\hline & & 1.8 & Produktivitas tanaman \\
\hline \multirow[t]{7}{*}{2} & Ekonomi & 2.1 & Kestabilan harga \\
\hline & & 2.2 & Kontribusi terhadap pendapatan per kapita \\
\hline & & 2.3 & Komoditas hortikultura yang unggul \\
\hline & & 2.4 & Harga produk hortikultura \\
\hline & & 2.5 & Pengelolaan hasil hortikultura \\
\hline & & 2.6 & Luas lahan garapan \\
\hline & & 2.7 & Pemanfaatan kredit pinjaman \\
\hline \multirow[t]{8}{*}{3} & Sosial & 3.1 & Eksistensi RT petani hortikultura \\
\hline & & 3.2 & Tingkat pendidikan masyarakat \\
\hline & & 3.3 & Status kepemilikan lahan \\
\hline & & 3.4 & Eksistensi layanan pemerintah \\
\hline & & 3.5 & Intensifikasi penyuluhan dan pelatihan \\
\hline & & 3.6 & Intensitas konflik lahan \\
\hline & & 3.7 & Persepsi masyarakat tentang kelestarian ekologi \\
\hline & & 3.8 & Pemahaman masyarakat tentang teknologi ramah ekologi \\
\hline \multirow[t]{7}{*}{4} & Teknologi & 4.1 & Tingkat penerapan teknologi \\
\hline & & 4.2 & Tingkat penguasaan teknologi pasca panen \\
\hline & & 4.3 & Teknologi pembuatan pupuk organik \\
\hline & & 4.4 & Teknik pembuatan mulsa \\
\hline & & 4.5 & Teknik pengolahan tanah \\
\hline & & 4.6 & Teknologi pembuatan biopestisida \\
\hline & & 4.7 & Teknologi konservasi tanah dan air \\
\hline \multirow[t]{7}{*}{4} & Kelembagaan & 5.1 & Ketersediaan Lembaga Keuangan Mikro \\
\hline & & 5.2 & Ketersediaan Lembaga Pemasaran \\
\hline & & 5.3 & Ketersediaan Lembaga Penyalur Saprodi \\
\hline & & 5.4 & Keberadaan Kelompok Tani \\
\hline & & 5.5 & Jumlah Penyuluh Pertanian \\
\hline & & 5.6 & Konflik antar Kelompok Tani \\
\hline & & 5.7 & Kelompok usaha di bidang pertanian \\
\hline
\end{tabular}

Sumber: Hasil Observasi dan Wawancara, 2019

\section{HASIL DAN PEMBAHASAN}

\subsection{Status Keberlanjutan Agribisnis Hortikultura di Kabupaten Sumba Barat}

Hasil analisis multidimensi (MDS) menunjukkan bahwa status keberlanjutan sistem agribisnis hortikultura di Kabupaten Sumba Barat berada pada kategori kurang berkelanjutan dengan nilai indeks sebesar 43.29 (Gambar 2). 


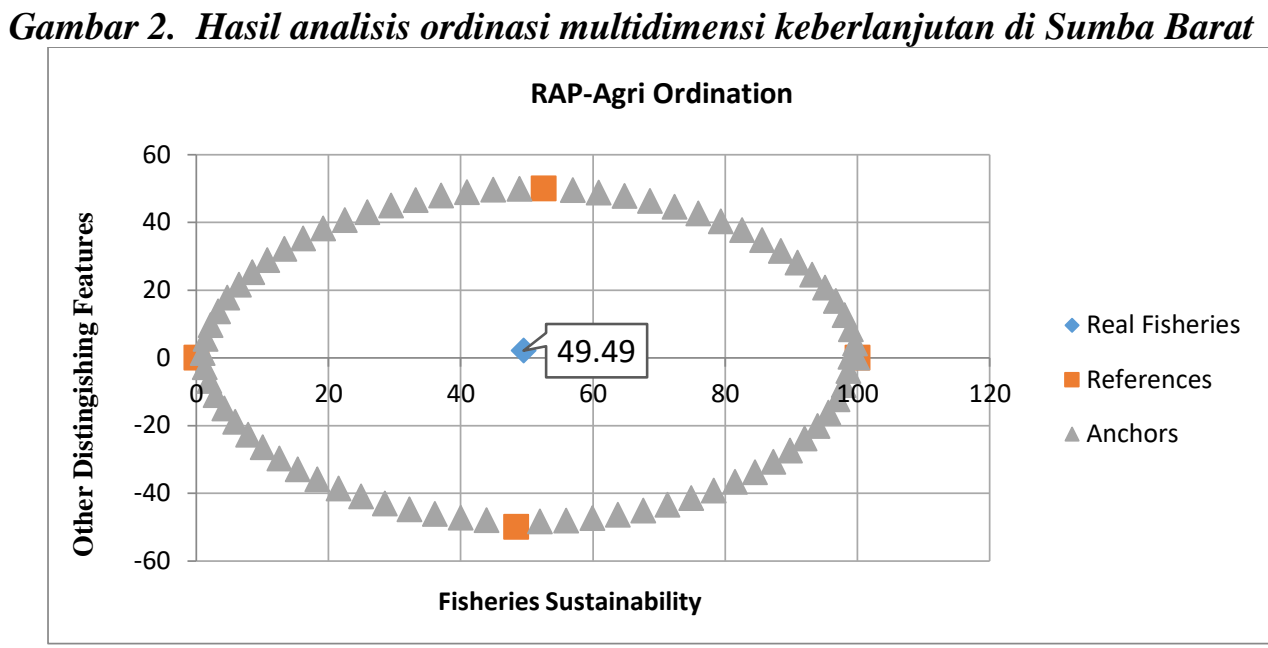

\subsection{Status Keberlanjutan dan Atribut Yang Dominan Pada Masing-masing Dimensi \\ 1) Dimensi Ekologi \\ a) Status Keberlanjutan}

Hasil analisis ordinasi dimensi ekologi menunjukkan bahwa agribisnis hortikultura di Sumba Barat berada pada level kurang berkelanjutan dengan nilai indeks sebesar 43,29 (Gambar 2).

Gambar 3. Hasil Analisis Ordinasi Dimensi Ekologi di Sumba Barat

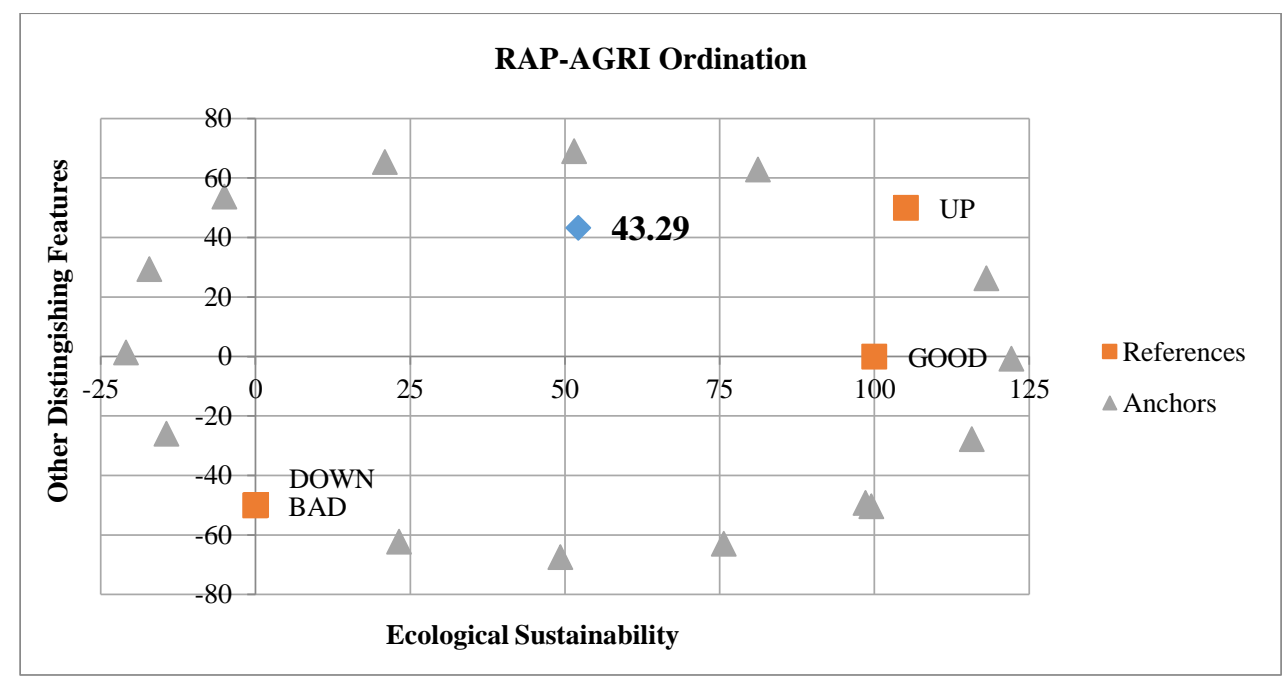

\section{b) Atribut Sensitif Dimensi Ekologi}

Analisis sensitivitas dilakukan untuk mengetahui atribut yang paling memberikan kontribusi terhadap nilai indeks keberlanjutan. Hasil analisis sensitivitas pada dimensi ekologi menunjukkan bahwa atribut yang memiliki nilai paling tinggi adalah penggunaan pupuk pestisida 
dengan nilai leverage 4,54. Hal ini mengindikasikan bahwa penggunaan pupuk dan pestisida merupakan atribut yang dominan mempengaruhi keberlanjutan sistem agribisnis hortikultura di Sumba Barat khususnya pada dimensi ekologi (Gambar 4).

\section{Gambar 4. Hasil Analisis Sensitivitas Dimensi Ekologi di Sumba Barat}

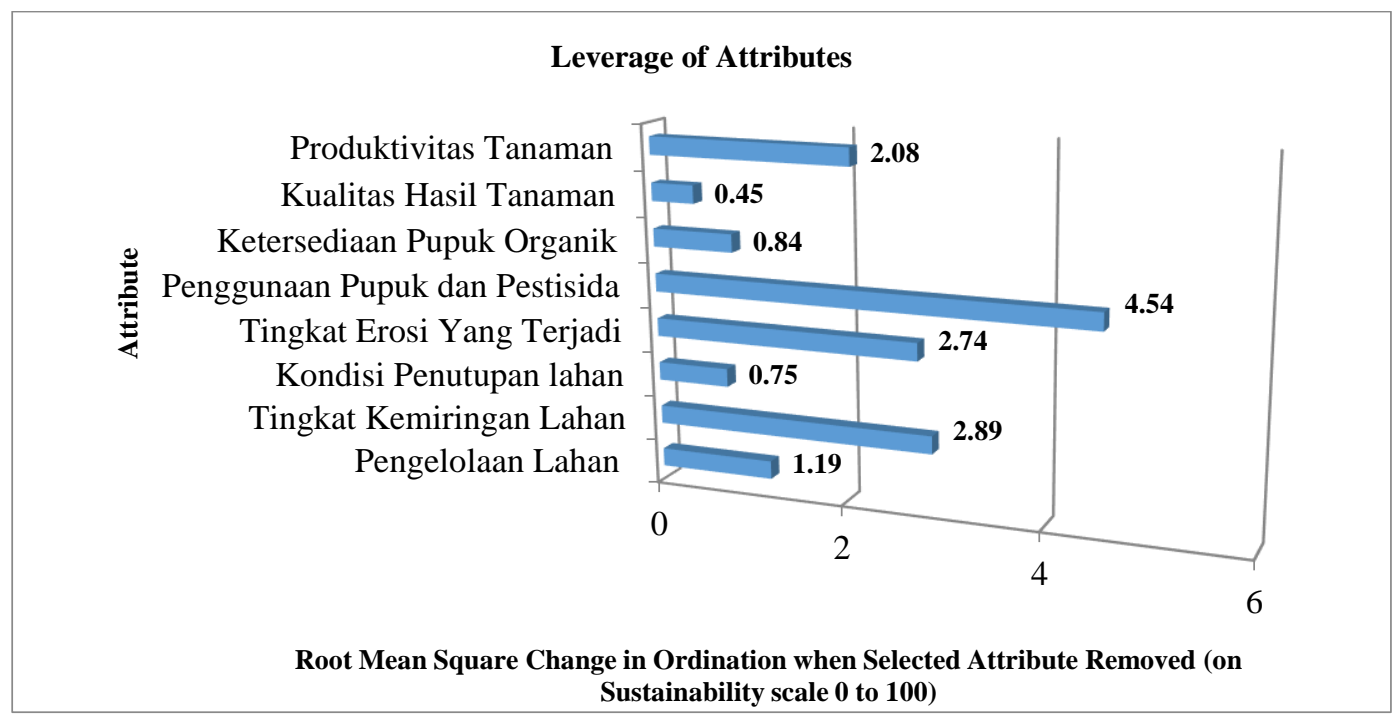

Penggunaan pupuk dan pestisida merupakan atribut yang dominan mempengaruhi keberlanjutan sistem agribisnis hortikultura di Kabupaten Sumba Barat. Sumba Barat memiliki beberapa kecamatan yang tergolong dalam kategori sebagai wilayah yang cukup subur dan beriklim sejuk dibandingkan tiga kabupaten lainnya di Pulau Sumba. Namun ada juga beberapa kecamatan yang beriklim panas cenderung kering terutama wilayah di dekat pesisir. Untuk wilayah dengan kondisi cenderung kering tersebut, penggunaan pupuk dan pestisida masih sangat diperlukan. Pupuk dan pestisida yang digunakan petani di Sumba Barat merupakan bantuan dari Pemerintah Daerah dan berbahan dasar kimia. Pilihan untuk menggunakan pupuk dan pestisida kimia tidak bisa dihindari karena petani belum memiliki kemampuan untuk membuat pupuk dan pestisida organik, termasuk kemampuan untuk membeli yang juga terbatas karena kekurangan modal. Namun ada juga beberapa petani sukses yang telah menggunakan pupuk organik hanya jumlahnya sedikit. Kondisi inilah yang mempengaruhi status keberlanjutan agribisnis hortikultura di Sumba Barat.

Atribut kedua yang cukup berpengaruh keberlanjutan agribisnis hortikultura di Sumba Barat adalah tingkat kemiringan lahan dengan nilai leverage 2,89. Daerah subur di Sumba Barat paling banyak berada di pegunungan, dengan tingkat kemiringan lahan yang cukup tajam. Petani hortikultura yang paling banyak berasal dari daerah pegunungan sehingga tingkat kemiringan 
lahan menjadi salah satu faktor yang mempengaruhi usaha tani di wilayah ini. Semakin tajam kemiringan lahannya maka dampaknya terhadap usaha tani akan semakin besar. Sementara kemampuan petani untuk membuat terasering juga terbatas karena minimnya pengetahuan.

Kemiringan lahan sangat berpengaruh terhadap tingkat erosi. Semakin curam kemiringan lahan maka semakin besar dampak erosi yang terjadi. Inilah yang menyebabkan tingkat erosi menjadi salah satu atribut yang mempengaruhi keberlanjutan agribisnis hortikultura di Sumba Barat. Namun selain persoalan tingkat kemiringan lahan, alih fungsi hutan juga dapat menyebabkan erosi pada wilayah pertanian berbasis hortikultura. Tingkat erosi makin tinggi terjadi pada musim hujan, terutama pada bulan Desember sampai April dimana curah hujannya makin tinggi Tentu saja, karakteristik lahan juga berpengaruh terhadap tingkat erosi khususnya lahan dengan kedalaman dan sifat lapisan tanah tanah tertentu yang akan mempengaruhi terhadap besarnya aliran permukaan erosi.

\section{2) Dimensi Ekonomi}

\section{a) Status Keberlanjutan}

Hasil analisis ordinasi dimensi ekonomi menunjukkan bahwa sistem agribisnis hortikultura di Sumba Barat berada pada level cukup berkelanjutan dengan nilai indeks sebesar 50,15 (Gambar5).

\section{Gambar 5. Hasil Analisis Ordinasi Dimensi Ekonomi di Sumba Barat}

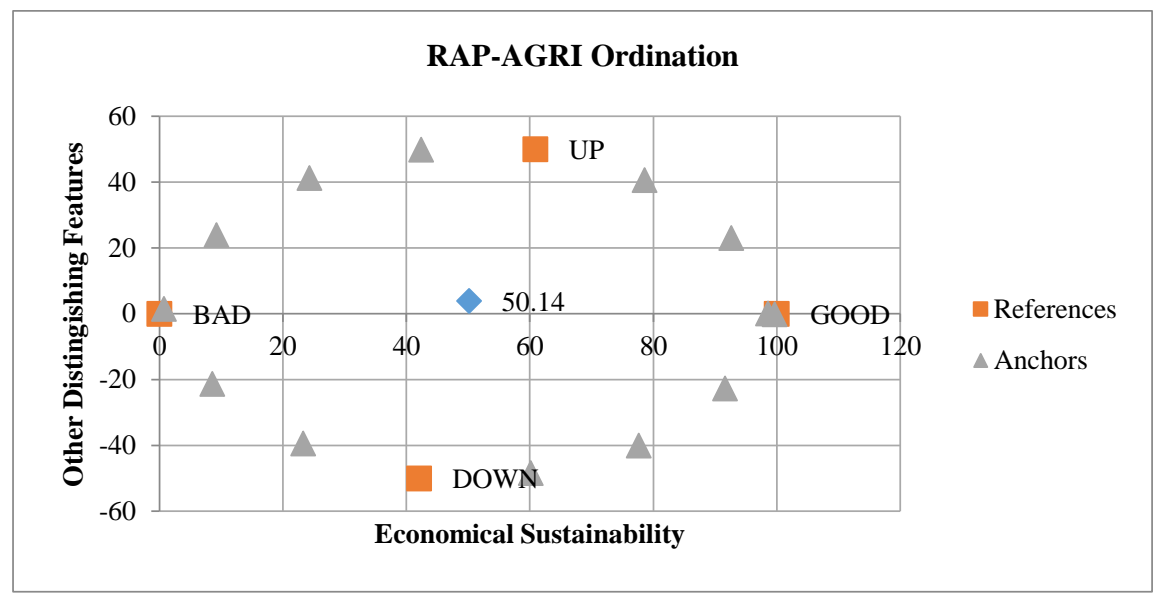

\section{b) Atribut Sensitif Dimensi Ekonomi}

Hasil analisis sensitivitas pada dimensi ekonomi menunjukkan bahwa atribut dengan nilai sensitivitas tertinggi adalah pengelolaan hasil hortikultura dengan nilai leverage 1,83 . Hal ini 
mengindikasikan bahwa pengelolaan hasil hortikultura merupakan atribut yang dominan mempengaruhi keberlanjutan agribisnis hortikultura di Sumba Barat khususnya pada dimensi ekonomi ( Gambar 6).

Gambar 6. Hasil Analisis Sensitivitas Dimensi Ekonomi di Sumba Barat

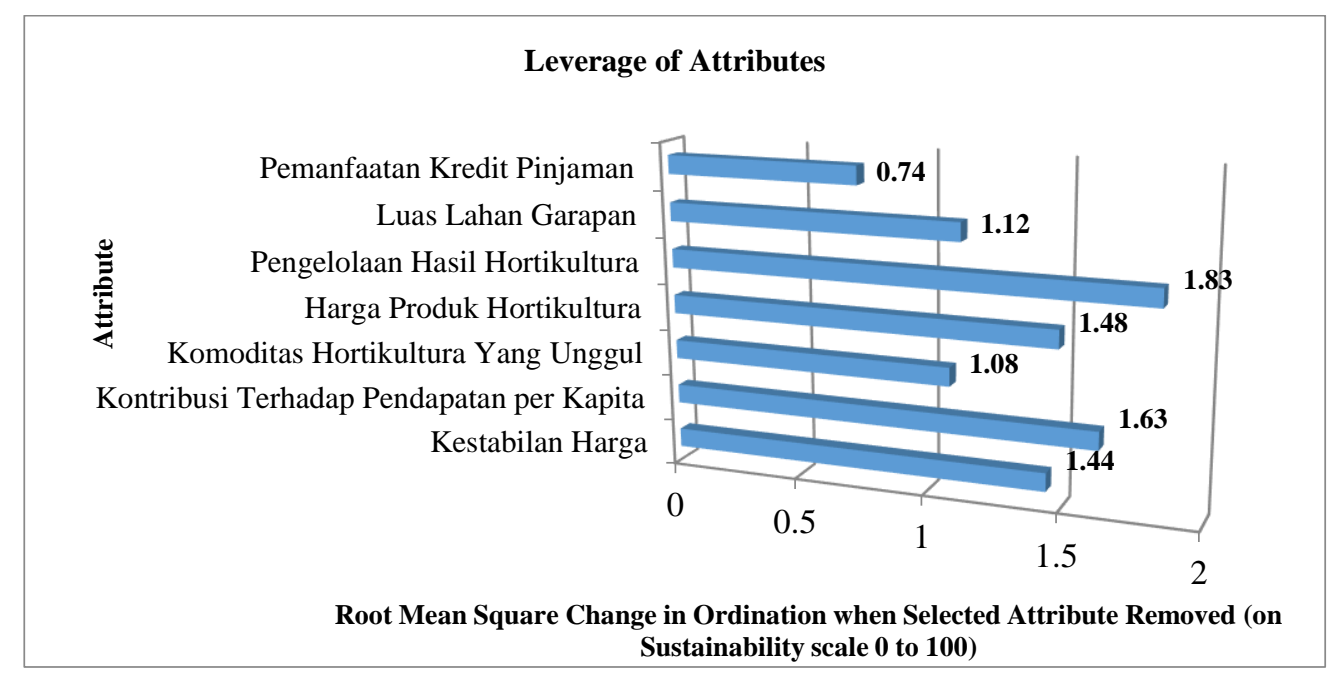

Pengelolaan hasil hortikultura merupakan atribut yang penting bagi petani di Sumba Barat. Berdasarkan hasil survey dan wawancara diketahui bahwa usaha pengelolaan hasil hortikultura di wilayah ini masih sangat terbatas. Petani memperoleh pendapatan paling besar hanya dari usaha budidaya dengan mekanisme pemasaran langsung, tanpa melalui proses pengelolaan. Beberapa keuntungan yang dapat diperoleh petani dari pengelolaan hasil hortikultura adalah (1) memperpanjang waktu dan jumlah persediaan pangan; (2) memudahkan penyimpanan dan distribusi; (3) memberikan nilai tambah secara ekonomi dan (4) mengurangi tingkat kerugian karena hasil tanaman hortikultura merupakan produk yang gampang rusak. Kendala yang dialami petani dalam kaitan dengan pengelolaan hasil hortikultura adalah kurangnya pengetahuan dan ketrampilan pengolahan pasca panen serta tidak adanya modal untuk memulai industri pengolahan.

Atribut yang juga berpengaruh terhadap keberlanjutan dimensi ekonomi adalah kontribusi terhadap pendapatan per kapita dengan nilai leverage 1,63. Usaha tani hortikultura di wilayah Sumba Barat masih merupakan usaha sampingan, sedangkan yang utama adalah usaha tani tanaman pangan pokok dan usaha tanaman umur panjang. Tanaman pangan pokok yang banyak dikembangkan oleh petani adalah padi, jagung, umbi-umbian dan kacang-kacangan. Sedangkan usaha tani tanaman umur panjang yang paling banyak adalah kopi, kemiri, jambu mete, dan vanili. Kondisi ini yang menyebabkan kontribusi penghasilan dari usaha tani hortikultura terhadap 
pendapatan per kapita tergolong rendah. Namun ada juga petani yang sumber utama penghasilannya berasal dari usaha tani hortikultura dan kebanyakan dari mereka merupakan petani sukses dengan pendapatan yang cukup tinggi dan stabil.

Harga produk hortikultura di Sumba Barat cenderung fluktuatif dimana pada musim panen harganya rendah karena jumlahnya berlimpah sedangkan ketika masa panen hampir habis maka harganya akan naik. Kondisi ini juga yang menjadi penyebab kontribusinya terhadap pendapatan per kapita cenderung rendah. Hal ini terlihat dari perbedaan yang cukup siginifikan antara pendapatan basis dan pendapatan non basis. Pendapatan basis adalah pendapatan dari usaha tani hortikultura sedangkan pendapatan non basis adalah sebaliknya. Pendapatan basis jauh lebih kecil dibandingkan pendapatan non basis karena (1) jumlah produksi hortikultura yang rendah, (2) harga produk hortikultura yang cenderung fluktuatif. Sedangkan pendapatan non basis lebih tinggi karena sumbernya cukup beragam, yakni dari hasil ladang atau sawah, ternak, tanaman umur panjang dan hasil kerajinan.

\section{3) Dimensi Sosial}

\section{a) Status Keberlanjutan}

Hasil analisis ordinasi dimensi sosial menunjukkan bahwa agribisnis hortikultura di Sumba Barat berada pada level kurang berkelanjutan dengan nilai indeks sebesar 48,26 (Gambar 7).

Gambar 7. Hasil Analisis Ordinasi Dimensi Sosial di Sumba Barat

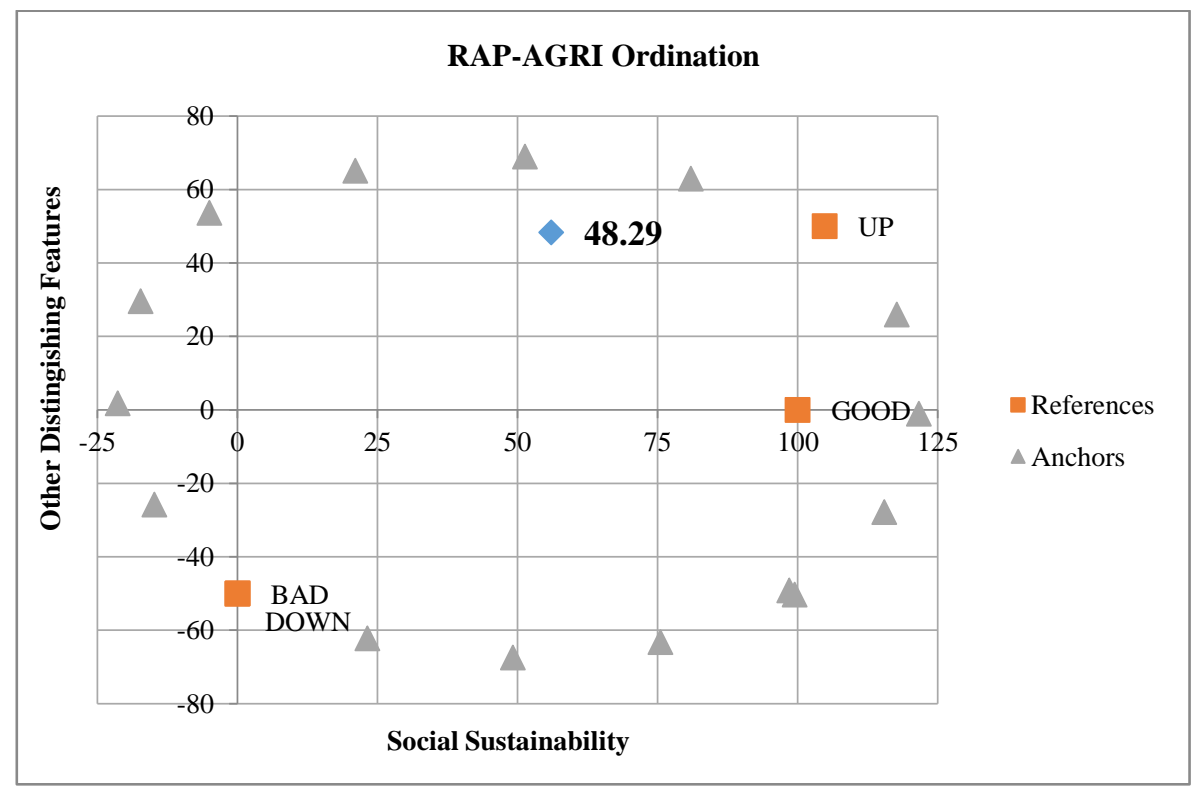




\section{b) Atribut Sensitif Dimensi Sosial}

Hasil analisis sensitivitas pada dimensi sosial menunjukan bahwa atribut dengan nilai leverage paling tinggi adalah eksistensi rumah tangga petani hortikultura $(4,82)$. Hal ini mengindikasikan bahwa eksistensi rumah tangga petani hortikultura merupakan atribut yang dominan mempengaruhi keberlanjutan agribisnis hortikultura pada dimensi sosial di Sumba Barat ( Gambar 8).

\section{Gambar 8. Hasil Analisis Sensitivitas Dimensi Sosial di Sumba Barat}

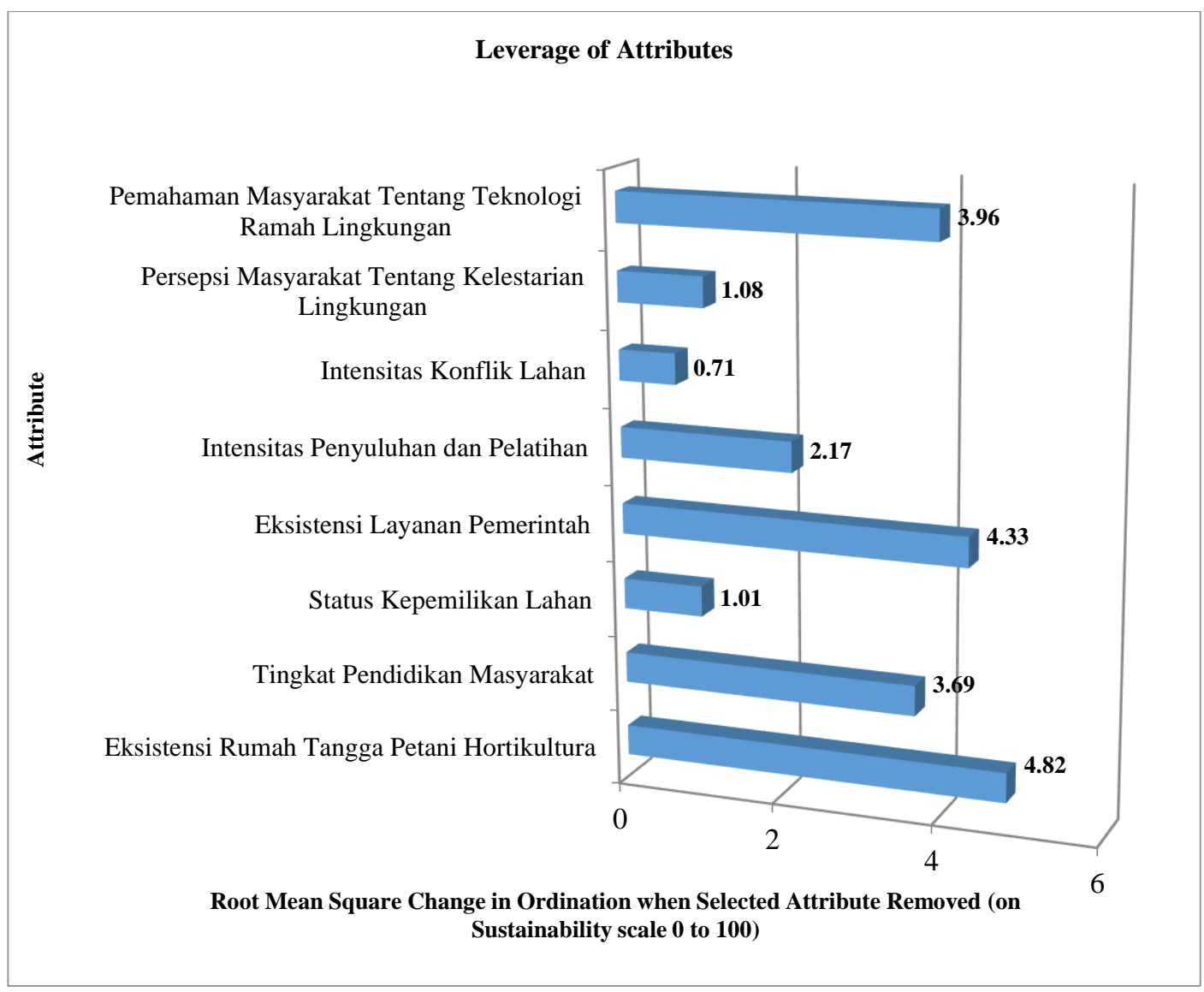

Pertanian skala kecil semakin menjadi perhatian dunia terutama semenjak PBB mengakui keberadaan dan peran pentingnya dalam mengatasi krisis pangan dunia. Di Indonesia, kesadaran akan pentingnya petani memperoleh perlindungan telah menjadi spirit lahirnya UU Perlindungan dan Pemberdayaan Petani tanggal 9 Juli 2013. Secara umum petani hortikultura di daerah dicirikan oleh penggunaan input yang rendah dan ramah lingkungan, namun tinggi dalam sensitivitas pertanaman (index of cropping), lebih intensif dan diversifikasif. Mereka dikenal sebagai petani kecil (small farmer) dengan ciri memiliki produksi terbatas namun lebih mandiri. Hal inilah yang 
menyebabkan pentingnya pengakuan akan eksistensi mereka terutama dalam hal pemenuhan kebutuhan pangan keluarga.

Persoalan eksistensi rumah tangga petani hortikultura menjadi atribut yang dominan mempengaruhi status keberlanjutan di Sumba Barat dengan nilai leverage 4,82. Sampai tahun 2016, jumlah RT Petani di Sumba Barat sebanyak 1.719 RT dan hampir semuanya menanam buah-buahan dan sayuran. Eksistensi rumah tangga petani hortikultura di Sumba Barat merupakan salah satu persoalan penting yang harus diselesaikan. Hasil survey menunjukkan bahwa pemahaman dan keberpihakan akan eksistensi mereka belum memadai serta masih adanya perlakuan yang kurang adil dari pemerintah. Sikap seperti ini akan melemahkan ketahanan pangan di wilayah Sumba Barat karena hampir sebagian besar masyarakat di wilayah ini merupakan petani. Eksistensi petani hortikultura harus diperhatikan dan diperkuat untuk mengikis kemiskinan, kelaparan, dan degradasi lingkungan di wilayah ini. Beberapa upaya yang dapat dilakukan adalah melalui peningkatan investasi pertanian agroekologis, memberi perhatian pada kearifan lokal, membantu akses mereka ke lembaga keuangan dan memperkuat organisasi tani.

Eksistensi layanan pemerintah juga merupakan atribut yang cukup berpengaruh terhadap keberlanjutan agribisnis hortikultura di Sumba Barat (nilai leverage 4,33). Berdasarkan hasil survey diketahui bahwa eksistensi layanan pemerintah mengacu pada intensitas pendampingan, sosialisasi dan penyuluhan yang diberikan kepada petani masih sangat kurang. Layanan pemerintah terhadap petani diwujudkan melalui Dinas Pertanian dan Badan Ketahanan Pangan Daerah. Pada tingkat kecamatan dan desa, layanan pemerintah diaktualisasikan melalui keberadaan Penyuluh Pertanian Lapangan atau PPL sebagai pendamping petani. Jumlah PPL di Sumba Barat sebanyak 63 orang dan jumlah desa sebanyak 77 desa sehingga masih kekurangan 11 orang PPL. Hal ini sangat berpengaruh terhadap eksisitensi layanan pemerintah terhadap petani (BPS Sumba Barat 2017). 
KAJIAN KEBERLANJUTAN AGRIBISNIS HORTIKULTURA DI KABUPATEN SUMBA BARATErnesta Leha

\section{4) Dimensi Teknologi}

\section{a) Status Keberlanjutan}

Hasil analisis ordinasi dimensi teknologi menunjukkan bahwa agribisnis hortikultura di Sumba Barat berada pada level kurang berkelanjutan dengan nilai indeks sebesar 43,79 (Gambar 9).

Gambar 9. Hasil Analisis Ordinasi Dimensi Teknologi di Sumba Barat

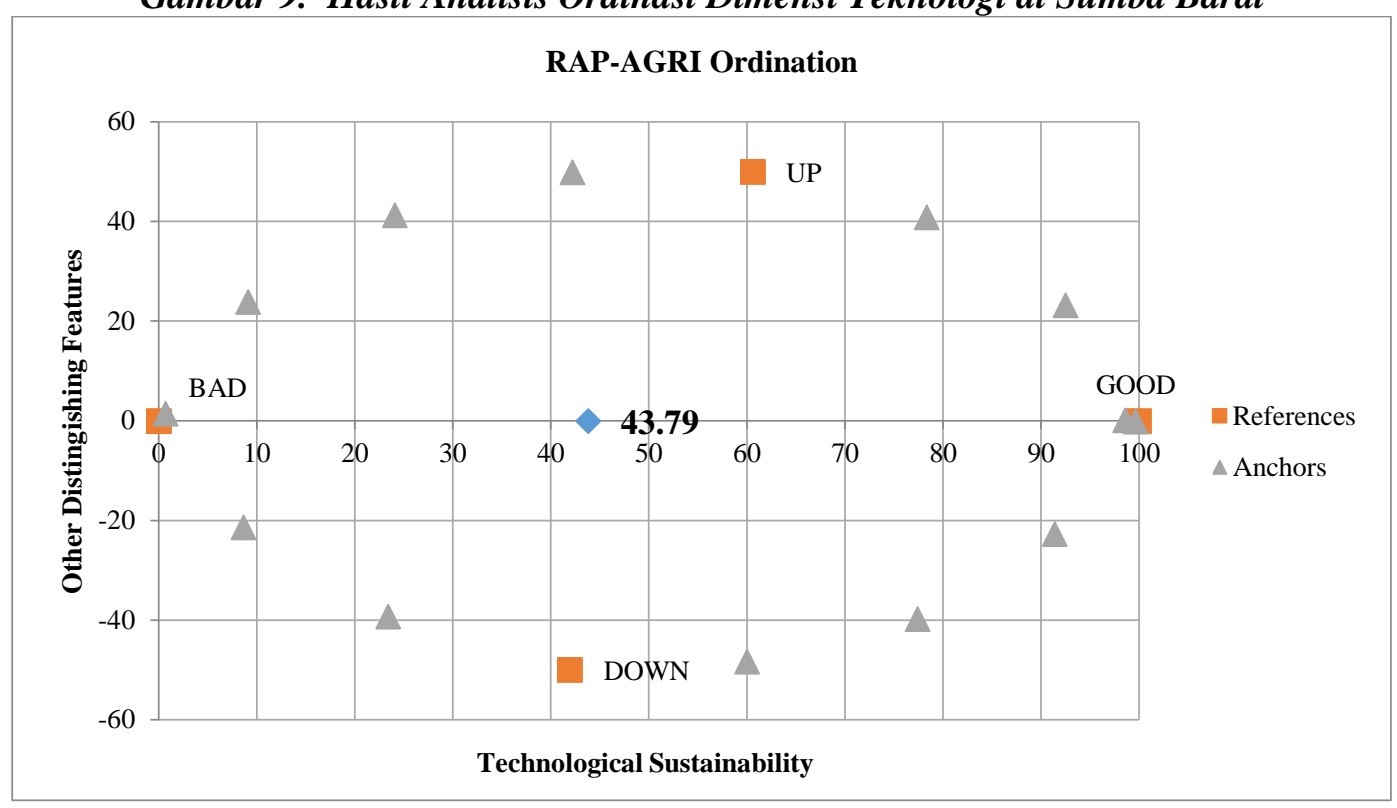

\section{b) Atribut Sensitif Dimensi Teknologi}

Hasil analisis sensitivitas pada dimensi teknologi menunjukkan bahwa teknologi konservasi tanah dan air mempunyai nilai leverage paling tinggi yakni 0,23. Hal ini mengindikasikan bahwa teknologi konservasi tanah dan air merupakan atribut yang dominan mempengaruhi keberlanjutan agribisnis hortikultura di Sumba Barat (Gambar 10). 
Gambar 10. Hasil Analisis Sensitivitas Dimensi Teknologi di Sumba Barat

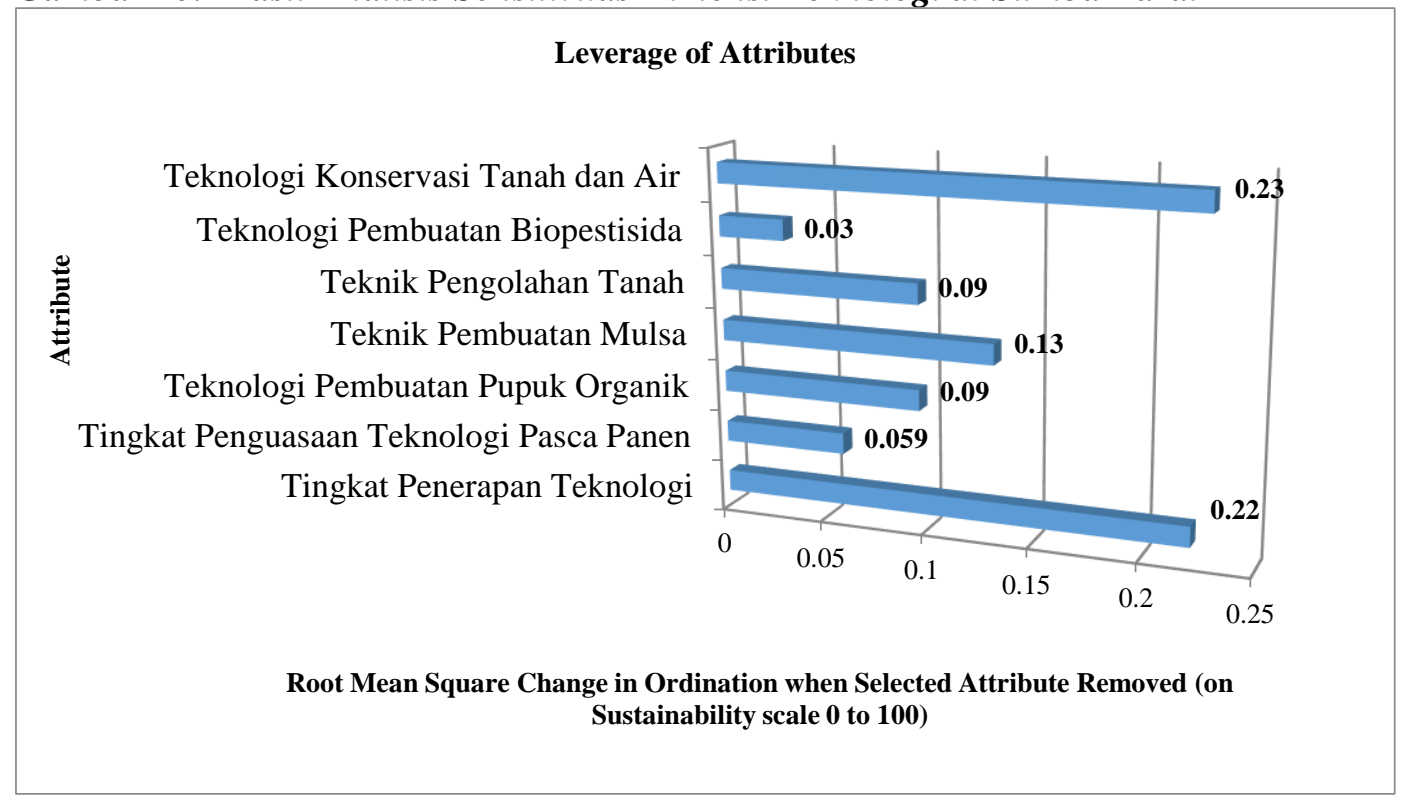

Persoalan teknologi tidak dapat dipisahkan dari pertanian secara umum dan pengembangan sub sektor hortikultura secara khusus. Perubahan teknologi (technology change) dan inovasi (innovation) adalah dua hal yang saling berkaitan. Kemajuan sub sektor hortikultura sangat tergantung pada seberapa besar kemajuan teknologi yang telah diserap oleh petani. Teknologi yang telah dikembangkan sampai saat ini semakin beragam di antaranya adalah teknologi benih yang menghasilkan benih unggul dengan produksi yang tinggi, teknologi pemupukan yang menghasilkan urea tablet, teknologi pengendalian hama dan penyakit termasuk teknologi pengembangan mesin budidaya dan mesin pasca panen. Kontribusi kemajuan teknologi ini telah banyak memberikan kontribusi bagi sub sektor hortikultura di banyak wilayah di Indonesia namun hal ini belum nampak di Sumba Barat.

Teknologi konservasi terhadap tanah dan air merupakan atribut yang dominan mempengaruhi keberlanjutan pengembangan hortikultura di Sumba Barat dengan nilai leverage 0.23. Keberlanjutan dari sisi ekologi erat kaitannya dengan kemampuan petani dalam melakukan konservasi terhadap tanah dan air. Hal ini yang masih belum dipahami oleh petani di Sumba Barat. Konservasi menurut Undang-undang adalah pengelolaan sumber daya alam hayati yang pemanfatannya dilakukan secara bijaksana untuk menjamin kesinambungan persediaannya dengan tetap memelihara dan menambahkan kualitas keanekagaraman dan nilainya. Pengetahuan dan teknologi konservasi tanah dan air yang belum dimiliki oleh petani memicu terjadinya degradasi lahan dan menyusutnya sumber-sumber air. Bahkan ada beberapa mata air yang mengering karena hutan di sekitarnya telah ditebang dan beralih fungsi menjadi pemukiman 
penduduk dan lahan pertanian. Oleh karena itu, kemampuan petani dalam kaitan dengan teknologi konservasi tanah dan air harus ditingkatkan agar kerusakan lingkungan dapat dikurangi.

Tingkat penerapan teknologi juga merupakan atribut yang cukup mempengaruhi keberlanjutan agribisnis hortikultura di Sumba Barat (nilai leverage 0,22). Berdasarkan hasil survey, sampai tahun 2016, petani di Sumba Barat masih melakukan usaha tani yang bersifat konvensional, belum nampak sentuhan teknologi dalam setiap tahapan budidaya hortikultura. Mulai dari pengolahan lahan yang masih menggunakan sarana dan prasarana seadanya sampai pada teknologi pasca panen yang masih minim di wilayah ini. Demikian halnya dengan teknologi informasi yang masih sulit dijangkau oleh petani. Padahal penerapan teknologi pada bisang usaha tani hortikultura sangat erat kaitannya dengan ketahanan pangan rumah tangga. Penerapan teknologi yang diharapkan untuk kondisi ini adalah penerapan yang efisien dan ekonomis serta berdayaguna tinggi.

\section{5) Dimensi Kelembagaan}

\section{a) Status Keberlanjutan}

Hasil analisis ordinasi dimensi kelembagaan menunjukkan agribisnis hortikultura di Sumba Barat berada pada level cukup berkelanjutan dengan nilai indeks sebesar 53,87 (Gambar $11)$.

Gambar 11. Hasil Analisis Ordinasi Dimensi Kelembagaan di Sumba Barat

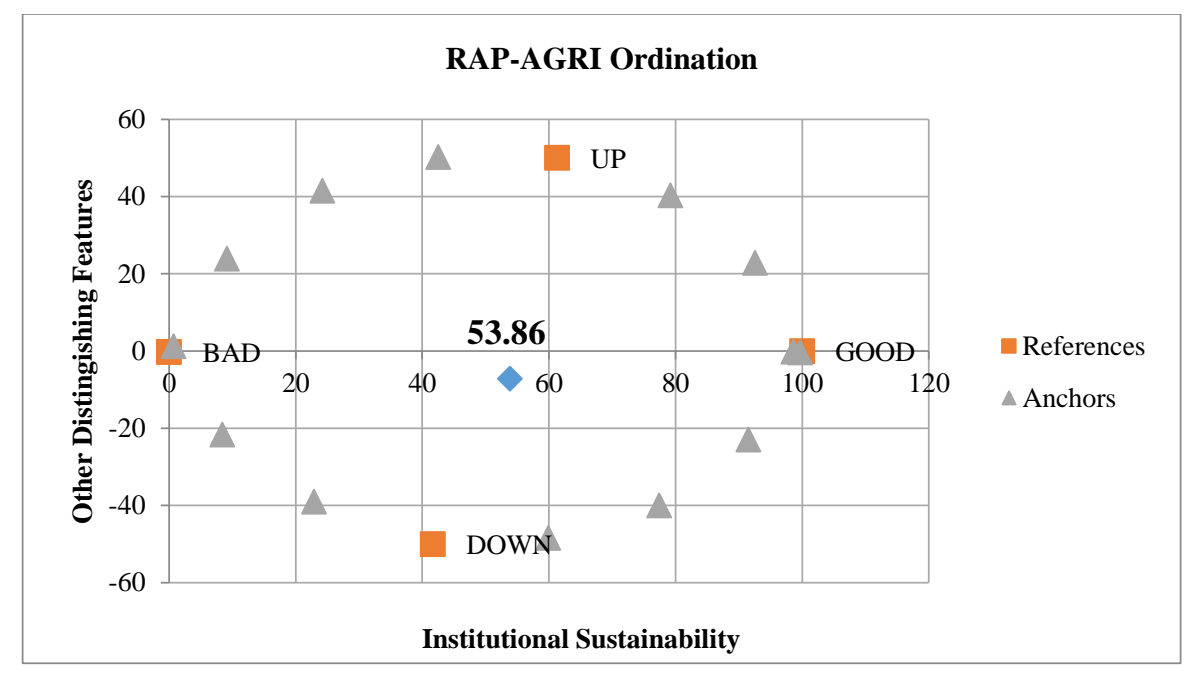

\section{b) Atribut Sensitif Dimensi Kelembagaan}

Hasil analisis sensitivitas pada dimensi kelembagaan menunjukkan bahwa konflik antar kelompok tani saat ini merupakan atribut yang nilai leverage paling tinggi yakni 3,62. Hal ini mengindikasikan bahwa konflik antar kelompok tani merupakan atribut yang dominan 
mempengaruhi keberlanjutan agribisnis hortikultura pada dimensi kelembagaan di Sumba Barat (Gambar 12).

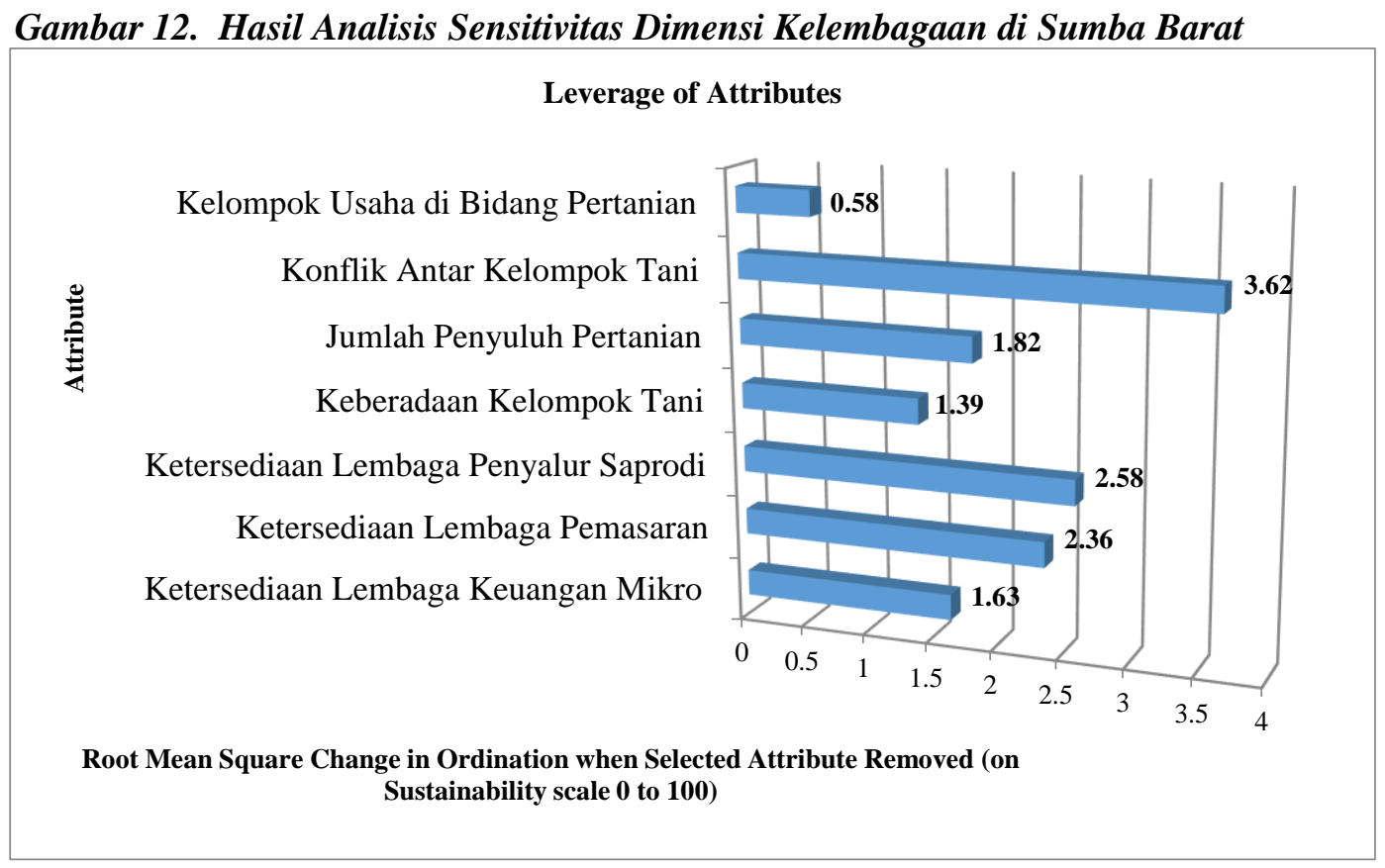

Secara defenitif, kelembagaan pertanian dapat dijelaskan sebagai norma atau kebiasaan yang terstruktur dan terpola serta diparketkkan terus menerus untuk memenuhi kebutuhan anggota masyarakat yang terkait dengan penghidupan dari bidang pertanian di perdesaan (Nasrul, 2012). Dalam konteks pengembangan hortikultura, fungsi kelembagaan memiliki nilai strategis dalam menggerakkan sistem agribisnis sub sektor tersebut di tingkat petani. Di tingkat nasional, peran kelembagaan dalam pengembangan sub sektor hortikultura sangat nampak dalam program intensifikasi dan peningkatan produksi yang dijalankan oleh Ditjen Hortikultura di bawah Kementerian Pertanian. Kondisi tersebut menunjukkan siginifikansi pemberdayaan kelembagaan dalam akselerasi pembangunan sub sektor hortikultura dan hal ini belum nampak di Kabupaten Sumba Barat sehingga status kelembagaannya berada pada level kurang berkelanjutan.

Status keberlanjutan agribisnis hortikultura di Sumba Barat dilihat dari dimensi kelembagaan berada pada level cukup berkelanjutan. Berdasarkan hasil analisis sensitivitas diketahui bahwa atribut yang dominan mempengaruhi status tersebut adalah konflik antar kelompok tani. Hal ini dapat diartikan bahwa kondisi kelembagaan pada tingkat petani cukup kondusif yang ditandai oleh minimnya konflik antar kelompok tani.

Ketersediaan lembaga penyalur Saprodi juga menjadi atribut yang sensitif berpengaruh terhadap keberlanjutan agribisnis hortikultura di Sumba Barat dengan nilai leverage 2,58. Sarana produksi pertanian atau Saprodi merupakan salah satu faktor penting dalam mendukung kemajuan 
usaha tani hodtikultura guna terciptanya ketahanan pangan wilayah. Benih, pupuk dan pestisida adalah sarana produksi pertanian utama yang paling banyak diperlukan petani. Benih yang unggul, pupuk dan pestisida organik merupakan komponen pertanian penting namun masih langka di Sumba Barat. Berdasarkan hasil survey hanya dua kabupaten yang memiliki lembaga penyalur saprodi yakni Sumba Timur dan Sumba Barat. Sedangkan petani dari wilayah Sumba Tengah dan Sumba Barat Daya harus memesan Saprodi dari kedua kabupaten tersebut, bahkan ada yang memesan Saprodi dari wilayah Flores bahkan dari Pulau Jawa dan Bali.

Atribut ketiga yang cukup mempengaruhi keberlanjutan adalah ketersediaan lembaga pemasaran dengan nilai leverage 2,36. Berdasarkan hasil survey, diketahui bahwa sampai tahun 2016, belum ada lembaga pemasaran yang solid dan bisa diandalkan di Sumba Barat. Menurut Kotler (2012), lembaga pemasaran timbul karena adanya keinginan konsumen untuk memperoleh komoditas yang sesuai waktu, tempat dan bentuk yang dinginkan konsumen. Tugas lembaga ini menjalankan fungsi-fungsi pemasaran serta memenuhi keinginan konsumen semaksimal mungkin. Konsumen memberikan balas jasa kepada lembaga pemasaran berupa marjin pemasaran. Sedangkan menurut Sunyoto (2012), lembaga pemasaran merupakan badan usaha atau individu yang menyelenggarakan pemasaran, menyalurkan jasa dan komoditi dari produsen kepada konsumen akhir serta mempunyai hubungan dengan badan usaha atau individu lain. Konsep pentingnya lembaga pemasaran ini yang belum terlalu dipahami, baik oleh petani maupun Pemerintah Daerah.

\subsection{Rangkuman Hasil Analisis Sensitivitas (Leverage) Keberlanjutan di Sumba Barat}

Hasil analisis leverage terhadap agribisnis hortikultura di Kabupaten Sumba Barat menunjukkan perbedaan status keberlanjutan pada masing-masing dimensi yakni dimensi ekologi dengan nilai indeks 43,29 (kurang berkelanjutan), dimensi ekonomi dengan nilai indeks 50,15 (cukup berkelanjutan), dimensi sosial dengan nilai indeks 48,26 (kurang berkelanjutan), dimensi teknologi dengan nilai indeks 43,79 (kurang berkelanjutan) dan dimensi kelembagaan dengan nilai indeks 53,87 (cukup berkelanjutan). Status kelima dimensi tersebut dapat digambarkan dalam diagram layang-layang (kite diagram) sebagaimana tersaji dalam Gambar 13. 


\section{Gambar 13. Kite Diagram Agribisnis Hortikultura di Sumba Barat}

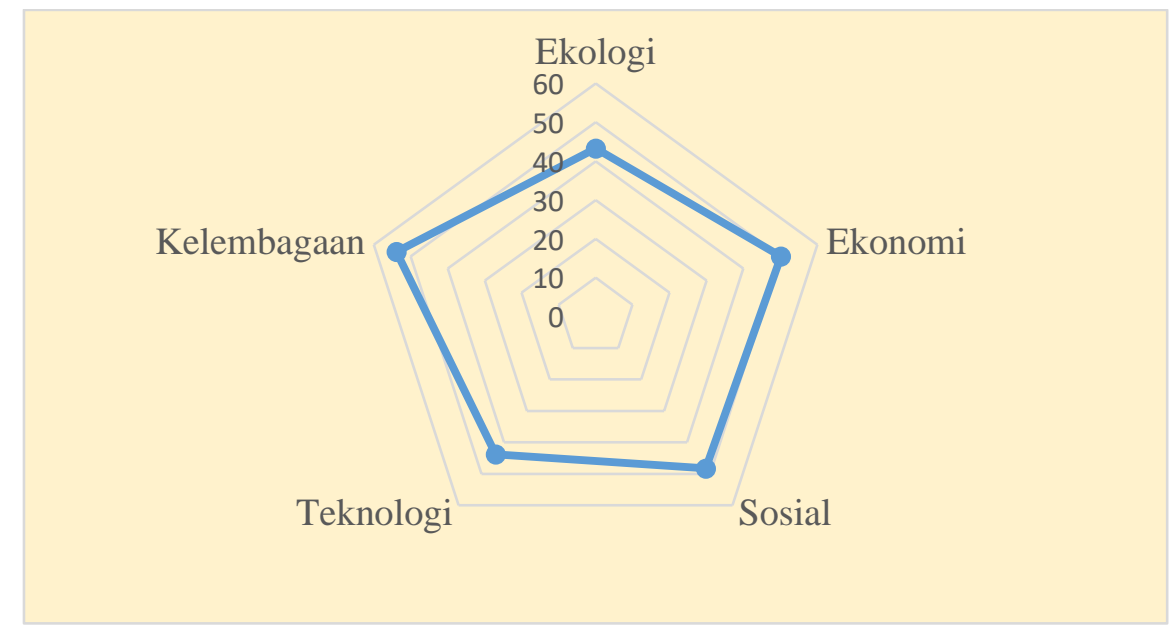

Hasil analisis leverage terdiri atas Rap-agri dan Monte Carlo output. Analisis Rap-agri berfungsi untuk mengetahui status keberlanjutan sedangkan analisis Monte Carlo adalah alat untuk menguji tingkat kepercayaan nilai leverage pada setiap dimensi. Perbedaan tingkat kepercayaan biasanya disebabkan oleh kesalahanan prosedur atau pemahaman terhadap atribut yang digunakan, variasi pemberian skor karena perbedaan pendapat, stabilitas proses analisis MDS, termasuk kesalahan memasukkan data atau adanya data yang hilang serta nilai stress yang terlalu tinggi. Semakin kecil perbedaan nilai analisis Rap-agri dan Monte Carlo berarti hasil analisis MDS memiliki tingkat kepercayaan yang tinggi, dengan kata lain, hasil analisisnya termasuk dalam kategori valid (Fauzi dan Anna, 2002). Perbedaan nilai antara Rap-agri dan Monte Carlo analysis dapat dilihat pada Tabel 5.

Tabel 5. Perbedaan nilai Rap-Agri dan Monte Carlo dalam analisis leverage

\begin{tabular}{llllll}
\hline \multirow{2}{*}{ Hasil } & \multicolumn{5}{c}{ Dimensi Keberlanjutan } \\
\cline { 2 - 6 } & $\mathrm{A}$ & $\mathrm{B}$ & $\mathrm{C}$ & $\mathrm{D}$ & $\mathrm{E}$ \\
\hline RAP-AGRI & 43,29 & 50,15 & 48,26 & 43,79 & 53,87 \\
Monte Carlo & 56,47 & 49,43 & 54,75 & 44,29 & 53,78 \\
Selisih Nilai & $-13,18$ & 0,72 & $-6,49$ & $-0,5$ & $-0,09$ \\
\hline
\end{tabular}

Keterangan : $A=$ Dimensi Ekologi; $B=$ Dimensi Ekonomi; $C=$ Dimensi Sosial; D=Dimensi Teknologi dan E=Dimensi Kelembagaan 


\section{KESIMPULAN}

Berdasarkan hasil analisis keberlanjutan di Kabupaten Sumba Barat diperoleh beberapa kesimpulan sebagai berikut :

a. Agribisnis hortikultura di Kabupaten Sumba Barat berada pada status cukup berkelanjutan untuk dimensi sosial dan kelembagaan sedangkan untuk dimensi ekologi, ekonomi dan teknologi berada pada status kurang berkelanjutan

b. Atribut yang dominan mempengaruhi keberlanjutan agribisnis hortikultura di Kabupaten Sumba Barat untuk masing-masing dimensi adalah (1) dimensi ekologi dipengaruhi oleh tingkat kemiringan lahan dan tingkat erosi yang terjadi; (2) dimensi ekonomi dipegaruhi oleh pengelolaan hasil hortikultura dan kontribusi terhadap pendapatan per kapita; (3) dimensi sosial dipengaruhi oleh eksistensi rumah tangga hortikultura dan eksistensi layanan pemerintah; (4) dimensi teknologi dipengaruhi oleh teknologi konservasi tanah dan air serta penerapan teknologi dan (5) dimensi kelembagaan dipengaruhi oleh konflik antar kelompok tani, ketersediaan lembaga pemasaran dan jumlah penyuluh pertanian

\section{DAFTAR PUSTAKA}

Bungaran Saragih. 2010. Agribisnis paradigma baru pembangunan ekonomi berbasis pertanian. IPB Press, Bogor

Biro Pusat Statistik Sumba Barat. 2013. Kabupaten Sumba Barat Dalam Angka. BPS, Waikabubak Biro Pusat Statistik Sumba Barat. 2015. Kabupaten Sumba Barat Dalam Angka. BPS Waikabubak Biro Pusat Statistik. 2017. Kabupaten Sumba Barat Dalam Angka. BPS, Waikabubak

Biro Pusat Statistik Nusa Tenggara Timur. 2013. Provinsi Nusa Tenggara Timur Dalam Angka. BPS, Kupang

Biro Pusat Statistik Nusa Tenggara Timur. 2015. Provinsi Nusa Tenggara Timur Dalam Angka. BPS, Kupang

Biro Pusat Statistik Nusa Tenggara Timur. 2017. Provinsi Nusa Tenggara Timur Dalam Angka. BPS, Kupang

Direktorat Jenderal Hortikultura, 2014. Statistik hortikultura. Kementerian Pertanian, Jakarta

Eriyatno. 2012. Ilmu sistem: Meningkatkan integrasi dan dan koordinasi manajemen. Jilid 2 Ed ke-4. Penerbit Guna Widya, Surabaya

Fauzi A. 2002. Penilaian depresiasi sumberdaya perikanan sebagai bahan pertimbangan penentuan kebijakan pembangunan perikanan. Jurnal Pesisir dan Kelautan 4 (2): 36-49 
Fauzi, A. dan S. Anna, 2005. Pemodelan sumber daya perikanan dan lautan untuk analisis kebijakan. Gramedia Pustaka Utama, Jakarta

Kotler P.2012. Manajemen pemasaran. Edisi ke-13.Penerbit Erlangga, Jakarta

Kepmen LH No.201Tahun 2004. Kriteria baku dan pedoman penentuan kerusakan mangrove. Kementerian Lingkungan Hidup, Jakarta

KEMENTAN RI.2014. Rencana Strategis Kementerian Pertanian 2015-2019. Kementerian Pertanian, Jakarta

Kuncoro M.2014. Otonomi daerah : Menuju era baru pembangunan daerah. Penerbit Erlangga, Jakarta

Kuncoro M. 2011. Metode riset untuk bisnis dan ekonomi : Bagaimana meneliti dan menulis thesis. Jakarta. Penerbit Erlangga, Jakarta

Nasrul W. 2012. Pengembangan kelembagaan pertanian untuk peningkatan kapasitas petani terhadap pembangunan pertania. Menara Ilmu, 29 (3) : 166 - 174

Pitcher, T. J. and D. Preikshot. 2001. Rapfish: A rapid appraisal technique to vvaluate the sustainability status of fisheries. Fisheries Research 49 (2001): 255-270

Pattimahu, Debby V. 2010. Kebijakan pengelolaan hutan mangrove berkelanjutan di Kabupaten Seram Bagian Barat, Maluku. Disertasi. Institut Pertanian Bogor, Bogor

Poerwanto R dan Susila DA. 2013. Teknologi hortikultura. IPB Press, Bogor

Rosidin U. 2015. Otonomi Daerah dan Desentralisasi. Pustaka Setia, Jakarta.

Saragih B. 2010. Pembangunan sektor agribisnis dalam kerangka pembangunan ekonomi Indonesia. Bappenas, Jakarta

Soekartawi, A Soeharjo, John L Dillon, J.Brian Hadaker. 2011. Ilmu usaha tani. UI Press, Jakarta Suweda. 2011. Penataan ruang perkotaan yang berkelanjutan, berdaya saing dan berotonomi. J Ilmiah Teknik Sipil. 5 (2) : 113-122

Soekartawi. 2011.Agribisnis: Teori dan aplikasinya. Raja Grafindo Persada, Jakarta

Saida, Sabiham S, Sutjahja SH dan Widiatmaka. 2011. Analisis keberlanjutan usahatani hortikultura sayuran pada lahan lereng di Hulu DAS Jeneberang Sulawesi Selatan. J Matematika Sains dan Teknologi.12(1): 110-112

Sunyoto D. 2012. Dasar-dasar manajemen pemasaran. PT Buku Seru, Yogjakarta

Thamrin, Sutjahjo SH, Herison C dan Sabiham S. 2007. Analisis keberlanjutan wilayah perbatasan Kalimantan Barat-Malaysia untuk pengembangan kawasan agropolitan. J.Agro Ekonomi.25(2): 103-124

Theresia A dan Toto. 2014. Pembangunan berbasis masyarakat. Penerbit Alfabeta, Jakarta 